OPEN ACCESS

Edited by:

Steven E. Mock

University of Waterloo, Canada

Reviewed by:

Jonathan Wai,

Duke University, USA

David Biek

Middle Georgia State University, USA

*Correspondence:

Sebastian Bergold sebastian.bergold@tu-dortmund.de

Specialty section: This article was submitted to Developmental Psychology, a section of the journal

Frontiers in Psychology

Received: 14 May 2015 Accepted: 07 October 2015 Published: 20 October 2015

Citation: Bergold S, Wirthwein L, Rost $D H$ and Steinmayr R (2015) Are gifted adolescents more satisfied with their lives than their non-gifted peers?

Front. Psychol. 6:1623. doi: 10.3389/fpsyg.2015.01623

\section{Are gifted adolescents more satisfied with their lives than their non-gifted peers?}

\author{
Sebastian Bergold ${ }^{1 *}$, Linda Wirthwein ${ }^{1}$, Detlef H. Rost ${ }^{2,3}$ and Ricarda Steinmayr ${ }^{1}$ \\ ${ }^{1}$ Department of Psychology, Technical University of Dortmund, Dortmund, Germany, ${ }^{2}$ Faculty of Psychology, Southwest \\ University Chongqing, Chongqing, China, ${ }^{3}$ Department of Psychology, Philipps-Universität Marburg, Marburg, Germany
}

Studies investigating the life satisfaction of intellectually gifted and non-gifted students are scarce and often suffer from methodological shortcomings. We examined the life satisfaction of gifted and non-gifted adolescents using a rather unselected sample of $N=655$ German high-school students ( $n=75$ gifted), adequate comparison groups of non-gifted students, and a clear definition of giftedness (general intelligence $g>2$ SD above the mean). There was no difference in life satisfaction between gifted and non-gifted adolescents $(d<|0.1|)$. Girls reported somewhat lower life satisfaction scores than boys $(d=0.24)$. However, this result was not specific to giftedness but was instead found across the entire sample. Thus, gifted girls were not found to be especially unsatisfied with their lives. Our findings support previous research showing that giftedness is not a risk factor for impaired psycho-social well-being of boys or girls.

Keywords: life satisfaction, giftedness, subjective well-being, intelligence, adolescents, gender differences

\section{INTRODUCTION}

In recent decades, there has been a growing interest in the questions of whether certain groups of individuals are more satisfied with their lives than others and which individual determinants contribute to the subjective well-being of an individual (e.g., Eid and Larsen, 2008). Research has shown that individual characteristics (e.g., personality variables; see Lucas, 2008) contribute to a person's life satisfaction and well-being. Diener (1984, p. 559) supposed that "intelligence is a personality variable that would be expected to relate strongly to subjective well-being because it is a highly valued resource in this society." Hence, one could assume that people who score high on intelligence tests-intellectually gifted individuals-might be more satisfied with their lives than non-gifted individuals. However, there is still a tendency to assume that gifted individuals are at higher risk for developing emotional and social difficulties and might report a lower life satisfaction than non-gifted individuals (e.g., Ziegler and Raul, 2000). Empirical research focusing on the life satisfaction of gifted adolescents is scarce (e.g., Neihart, 1999; Jones, 2014), and the few existing studies have been plagued by various methodological shortcomings such as small and/or preselected samples and/or a lack of appropriate comparison groups and/or imprecise definitions and operationalizations of giftedness. Thus, the aim of the current study was to shed some light on the life satisfaction of adolescents by using reliable and valid instruments to assess intellectual giftedness as well as life satisfaction and by comparing a rather unselected group of gifted adolescents with an appropriately matched non-gifted group. 


\section{Defining Intellectual Giftedness and Life Satisfaction}

There are several different definitions of "intellectual giftedness" (Sternberg and Davidson, 2005), and many of them advocate a multidimensional approach. For example, some conceptions assign major roles to creativity and motivational constructs and regard giftedness as high achievement rather than as high potential (e.g., Renzulli, 1978; Mönks, 1990). However, there are many theoretical as well as methodological reasons to consider high general intelligence to be the core indicator of giftedness (see Rost, 2013). For example, intelligence is a highly stable construct and the best singular psychological predictor of many important life outcomes such as scholastic achievement, professional success, and socio-economic status. Furthermore, many multidimensional models require high scores on several different constructs, thus posing the problem that the group of gifted individuals will shrink and finally vanish as the number of constructs rises. Also, intelligence can be reliably assessed, and many sound intelligence tests are available, whereas measures of, for example, creativity and motivation often suffer from lower psychometric properties and poor validity in direct comparison with intelligence tests (see Robinson, 2005). Thus, the use of intelligence test scores (IQ > 2 SD above the mean) to define giftedness has prevailed in the empirical literature (Rost, 1993; Roznowski et al., 2000; Wirthwein and Rost, 2011; Baudson and Preckel, 2013).

Comparable to the various definitions of giftedness, there are also a lot of different conceptualizations of well-being (e.g., life satisfaction, happiness, quality of life), and this makes it difficult to compare the results found in different studies. In the current study, we focus on the construct of life satisfaction because it has been investigated more frequently than other well-being variables and is seen as the most stable component of subjective well-being (Suldo et al., 2006). Life satisfaction refers to a "global evaluation by the person of his or her life" (Pavot et al., 1991, p. 150). It has frequently been examined in the context of subjective well-being, including cognitive (i.e., life satisfaction) as well as emotional components (i.e., positive and negative affect; see Diener et al., 1999). Besides judgments of global life satisfaction, satisfaction in different domains (e.g., satisfaction with school, family, friends) can be differentiated (Diener et al., 1999).

In the current study, we rely on global life satisfaction selfreports of gifted and non-gifted adolescents identified via a wellestablished intelligence test. We focus in particular on gifted and non-gifted adolescents because this age group might be especially susceptible to low life satisfaction (e.g., Gilman and Huebner, 2003).

\section{Intellectual Giftedness and Life Satisfaction}

Terman was the first to study the life satisfaction of intellectually gifted individuals in his outstanding longitudinal study "Genetic studies of genius" (e.g., Sears, 1977), indicating a positive relation between intelligence and life satisfaction. The life satisfaction of gifted individuals was also investigated in the Study of
Mathematically Precocious Youth, drawing on large samples. The study found that the gifted individuals (in early and middle adulthood) displayed high levels of life satisfaction (Lubinski et al., 2006, 2014) and high self-esteem (Swiatek and Benbow, 1991). Diener and Fujita (1995) supposed that people with high personal resources (inter alia high intelligence) are better able to achieve their goals and, hence, might be happier than people with low personal resources. Correlational studies conducted with children and adolescents have mainly found negligible associations between intelligence and life satisfaction (e.g., Huebner and Alderman, 1993: $r=-0.08$; Chmiel et al., 2012: $\beta=0.04$ ). Negligible associations have also been found in studies investigating life satisfaction and intelligence in adults (e.g., Watten et al., 1995; Rode et al., 2008). Studies focusing on different affective well-being measures have shown heterogeneous associations with intelligence. For example, Kirkcaldy et al. (2004) analyzed students from different international large scale assessments and found a correlation between happiness and intelligence of $r=0.44$, whereas Owuchi and Yoshino (1975) reported a correlation of only $r=0.07$.

There are two different hypotheses about the social and emotional characteristics of the gifted: the harmony hypothesis and the disharmony hypothesis (e.g., Mönks, 1963). According to the harmony hypothesis, gifted individuals show a more balanced personality profile and are, for example, more successful and more socially competent than non-gifted individuals (e.g., Plucker and Callahan, 2008). Hence, according to this hypothesis, gifted individuals should report higher life satisfaction than non-gifted individuals. However, according to the disharmony hypothesis, gifted people should show social and emotional difficulties and a higher risk for developmental disorders compared with the non-gifted (e.g., Neihart, 1999).

Most empirical research has shown support for the harmony hypothesis: differences between gifted and non-gifted individuals across various age groups and various emotional and psychosocial variables are mainly in favor of the gifted or are rather negligible (Czeschlik and Rost, 1988; Rost, 1993, 2009; Plucker and Callahan, 2008). For example, gifted students were found to be somewhat more popular and somewhat less rejected by their classmates than non-gifted students (Rost and Czeschlik, 1994a; Czeschlik and Rost, 1995). In a study by Rost and Czeschlik (1994b), gifted and nongifted 10-year-olds did not differ in psycho-social adjustment, namely anxiety, extraversion, diffidence, sociability, problem behavior, or social contacts, as indicated by their parents, their teachers, and the children themselves. Results were largely the same for adolescents: there were no differences between gifted and non-gifted adolescents in social integration, emotional state, or number of friends. If anything, gifted adolescents had somewhat less contact with their friends but were, however, not socially isolated (Schilling, 2002; Rost, 2009). Furthermore, they had a high level of confidence in their cognitive abilities and a low level of fear of failure (Neitzke and Röhr-Sendlmeier, 1992; Schütz, 2009). Results supporting the disharmony hypothesis have mainly been due to the methodological shortcomings of the studies such as the use 
of preselected and very small samples (e.g., from counseling centers or by using students who attend special gifted courses), often in combination with the lack of an adequate non-gifted control group. Moreover, gifted individuals are frequently not identified via reliable and valid intelligence tests but instead via teacher, peer, or parent nominations (see Rost, 1990, 2009), and the definitions of giftedness vary considerably across different studies.

Taking into account those studies that have employed a nongifted control group, gifted individuals do not differ from nongifted groups in mental health or various well-being measures (e.g., Zeidner and Shani-Zinovich, 2011; Jones, 2014). But only a few studies have explicitly examined the life satisfaction (i.e., the cognitive component of subjective well-being) of gifted compared with non-gifted adolescents. Ash and Huebner (1998) compared $n=61$ gifted middle school students with $n=61$ non-gifted students. They found an effect size of $d=0.24$ in favor of the gifted. Shaunessy et al. (2006) compared $n=33$ gifted adolescents with $n=179$ other students from the same school. The effect was not statistically significant and very small $(d=0.14$ in favor of the gifted). In a study by Loeb and Jay (1987), effect sizes ranging from $d=0.03$ to $d=0.50$ (again in favor of the gifted) were detected in $n=125$ gifted and $n=102$ nongifted fourth to sixth graders across different well-being measures (but not explicitly life satisfaction). Other studies focusing on different well-being measures in children and adolescents (Chapman and McAlpine, 1988; Jin and Moon, 2006) have shown comparable results. Although the aforementioned studies included comparison groups, they still had some methodological shortcomings: for example, the study by Ash and Huebner (1998) used teacher recommendations, grades, and student interviews to identify gifted students, and Shaunessy et al. (2006) also used teacher nominations and grades besides intelligence test scores; in addition, the gifted students were enrolled in a special course for gifted and talented students. However, the results found for adolescents were comparable to the results found for gifted adults in a methodologically sound study by Wirthwein and Rost (2011). In this study, intelligence test scores were exclusively used to identify intellectually gifted and nongifted adults, and the gifted individuals were not preselected via teacher nominations or parents. Moreover, the control group was matched on age, gender, and socio-economic status. The authors found no statistically significant difference between the two groups on global life satisfaction as well $(d=0.16$ in favor of the gifted).

Several other studies have been conducted on gifted adolescents, mainly focusing on variables such as self-concept or other measures of mental health (see Martin et al., 2010; Zeidner and Shani-Zinovich, 2011; Jones, 2014). These studies also found only small or negligible differences between the investigated groups, again supporting the harmony hypothesis.

Some researchers have argued that gifted girls compared with gifted boys are at a particularly higher risk for developing emotional or social difficulties (see Reis, 2004), and hence, gifted girls might report lower life satisfaction. This research topic has received little attention so far. To our knowledge, only Wirthwein and Rost (2011) investigated gender differences in life satisfaction between gifted and non-gifted adults. The authors did not find a giftedness $\times$ gender interaction of statistical or practical significance $\left(\eta^{2}=0.01\right)$. We are not aware of any study that has focused on gender differences in gifted adolescents' life satisfaction while also taking into account non-gifted adolescents' life satisfaction.

\section{The Present Study}

The aim of the present study was to shed some light on the life satisfaction of gifted compared with non-gifted adolescents. As already mentioned, previous studies have suffered from several methodological shortcomings such as imprecise definitions of giftedness, lack of an appropriately matched non-gifted control group, or small preselected samples. With our study, we tried to avoid some of these shortcomings. Therefore, we analyzed the data of a relatively unselected sample, and we used the results from a well-established intelligence test as the criterion to define intellectual giftedness (see Robinson, 2005; Rost, 2009). Moreover, we analyzed a comparable group of non-gifted adolescents. With regard to the few methodologically sound existing studies that have focused on the life satisfaction of gifted individuals, we expected that gifted individuals would report similar or higher life satisfaction scores than non-gifted individuals (Ash and Huebner, 1998; Shaunessy et al., 2006; Wirthwein and Rost, 2011).

Another aim was to investigate whether gifted girls might display lower life satisfaction scores than gifted boys while also taking into account the life satisfaction scores of non-gifted girls and non-gifted boys. To our knowledge, this is the first study to investigate this research topic in a sample of adolescents. Thus, we did not formulate specific hypotheses concerning this topic.

\section{MATERIALS AND METHODS}

\section{Participants}

The sample comprised $N=655$ students (358 girls) attending a German Gymnasium. Students attended either the 11th or 12 th grade and were on average $M=16.65(S D=0.71)$ years of age. The Gymnasium is the highest track in the German secondary school system and the option most frequently chosen for receiving the Abitur, a school-leaving certificate that is mandatory for university enrollment. After finishing elementary school (4th grade), students are selected for one of several different school tracks. The highest performing students are selected for the Gymnasium (about 30-45\% of each cohort, depending on the specific local conditions). Thus, students attending a Gymnasium are high performing and are above average in intelligence (see Steinmayr et al., 2010), and the prevalence of gifted students is higher in Gymnasium samples than in the entire student population. Data from two studies were combined. The first study (see Amelang and Steinmayr, 2006) took place in 2004 and the second one in 2007 and 2008. Participation was voluntary. Written consent was obtained from the parents of the under-aged students. Samples did not differ with regard to the variables of interest in the present study. 


\section{Measures}

\section{Intelligence}

We administered the basic module of the Intelligence-StructureTest $2000 \mathrm{R}$ (Intelligenz-Struktur-Test 2000 R; IST 2000 R; Liepmann et al., 2007). This test is based on Thurstone's and Cattell's intelligence theories and measures verbal, numerical, and figural reasoning ability. The composite score indicates general reasoning ability, which is closely tied to general intelligence ( $g$; see Brand, 1996; Jensen, 1998). The IST $2000 \mathrm{R}$ is one of the most renowned and often applied intelligence tests in the German-speaking countries. Its psychometric properties and validity are well-established (e.g., Bühner et al., 2006; also see Schmidt-Atzert and Rauch, 2008). It is Z-scaled with a mean standardized intelligence score (SIS) of $M=100$ and $S D=10$.

Following Terman et al. (1925) and in accordance with other studies (e.g., Rost, 1990, 1993, 2009; Roznowski et al., 2000; Thompson and Oehlert, 2010), we defined giftedness as a high level of Spearman's $(1904,1927)$ general intelligence $g$, most often indicated by means of an intelligence score that is more than $2 \mathrm{SD}$ above the mean. Applied to the intelligence test we used, we diagnosed giftedness if a student's SIS was higher than 120 (i.e., if a student belonged to the upper 2 percent of the population). Accordingly, on the basis of their SIS, students were categorized into four different groups. The below-average (SIS $\leq 90$ ) group comprised $n=8$ students ( 7 girls; $M_{\text {age }}=17.25$ years, $\left.S D_{\text {age }}=1.49\right)$. An average SIS $(90<$ SIS $\leq 110)$ was displayed by $n=460$ students (286 girls; $M_{\text {age }}=16.66$ years, $S D_{\text {age }}=0.70$ ), and $n=112$ students ( 46 girls; $M_{\text {age }}=16.58$ years, $\left.S D_{\text {age }}=0.67\right)$ had above-average intelligence scores $(111 \geq$ SIS $\leq 120)$. A subsample of $n=75$ students (19 girls; $M_{\text {age }}=16.61$ years, $S D_{\text {age }}=0.72$ ) was categorized as gifted (SIS > 120). For propensity score matching (PSM; see below), we used only the average SIS group as the comparison group.

\section{Life Satisfaction}

Life satisfaction was measured with the General Life Satisfaction Scale developed by Dalbert (2003). It consists of seven items (e.g., "I am satisfied with my life," "I consider myself a happy person") that can be answered on a 7-point scale ( $1=$ "does not apply to me at all" to $7=$ "fully applies to me"). Negatively worded items were recoded so that high scores indicated high satisfaction with life. The scale measures the cognitive dimension of subjective well-being. It describes satisfaction with one's present and past life and with one's perspective on the future. In our study, the internal consistency (Cronbach's $\alpha$ ) of the General Life Satisfaction Scale was excellent ( $\alpha=0.93$ for the groups of gifted and non-gifted students).

\section{Sociodemographic Data}

All students reported their gender, age, and parents' highest school-leaving qualifications. The following categories were formed for the parents' qualifications: $0=$ no graduation, $1=$ lower secondary education (Hauptschulabschluss), 2 = secondary school certificate (Mittlere Reife), $3=$ entrance qualification for university of applied sciences (Fachhochschulreife), $4=$ Abitur. As an index of parental educational level, we used the sum of the highest school-leaving qualifications of both parents. Mothers' and fathers' educational levels were substantially correlated $(r=0.41, p<0.001)$. The possible range of the composite score was $0-8$.

\section{Procedure}

Testing sessions took place at school during a regular school day and were conducted in groups of about 20 students. Trained university students and research assistants administered the tests according to standardized instructions. Participation was voluntary, and students were allowed to take part only if their parents had completed written consent forms. All but five parents agreed. The participation rate in both student groups was about $90 \%$ : students who were not present when testing took place were absent due to illness or for other reasons that were not related to our investigation.

\section{Analyses \\ Propensity Score Matching}

In order to generate equivalent groups of gifted and non-gifted students, we used PSM (Rosenbaum and Rubin, 1983). PSM has received increasing attention in the social sciences in recent years as it is a valuable tool for establishing comparability between research groups. To calculate propensity scores, we used a logistic regression analysis with giftedness $(0=$ non-gifted, $1=$ gifted) as the dependent variable and the covariates age, gender $(0=$ male, $1=$ female), and parental educational level as predictors (method: inclusion) (Stuart, 2010). The matching procedure can be performed in several ways (see Thoemmes and Kim, 2011). For our analyses, we used 1:1 nearest neighbor matching without replacement. To ensure the quality of the matching result, we chose a relatively strict caliper of $c=0.1 \mathrm{SD}$ of the logit of the propensity score.

After matching, we analyzed differences in the means and variances of the covariates between the groups to test whether age, gender, and parental educational level were actually balanced between the groups (balance property). For this purpose, we used the overall balance $\chi^{2}$ test (Hansen and Bowers, 2008) as well as the $L_{1}$ statistic (e.g., Iacus et al., 2012). If good balance is achieved, the $\chi^{2}$ should be non-significant, and $L_{1}$ should be smaller for the matched samples than for the unmatched samples (Iacus et al., 2012). In addition, we inspected univariate statistics for the covariates. Differences in both the means and variances of the covariates should be close to 0 . The significance level was set at $5 \%$. We relinquished adjusting the $\alpha$ level in order to keep the $\beta$ error small. As our gifted sample (and consequently the matched sample of non-gifted students, due to $1: 1$ matching) was rather small, we additionally calculated Cohen's $d$. Values of $d \geq 0.80$ were considered to indicate a large effect, $d \geq 0.50$ a moderate effect, and $d \geq 0.20$ a small effect (Cohen, 1988).

Furthermore, we investigated the overlap in the propensity score distributions of the two groups (area of common support). Small areas indicate that effect estimation is restricted to a very specific subsample. By contrast, large areas suggest that the results are representative of the full range of the sample at hand (Thoemmes and Kim, 2011). 


\section{Group Comparison}

After testing for the balance property and inspecting the area of common support, group comparisons were performed. Because the matched nature of the data could affect the estimates of the standard errors and hence the significance level, there is some debate about whether it is permissible in such a situation to use statistics that assume independence of observations (Thoemmes and Kim, 2011). In the present study, we tested the results with corrected ( $t$-test for independent samples) and uncorrected ( $t$-tests for dependent samples) standard errors. Giftedness (gifted vs. non-gifted) was the independent grouping variable, and the score on the General Life Satisfaction Scale was the dependent variable.

When matching procedures are used, the target group is always compared with a control group that is preselected on certain characteristics and, hence, the generalizability of the results to the rest of the sample can be questioned. Therefore, we also tested whether our findings from the PSM would hold with a relatively unselected comparison group. Since we aimed to control for gender, we used the data that were available from all of the boys (56 gifted and 241 non-gifted) and from the gifted girls $(n=19)$ and drew a random sample of $n=82$ non-gifted girls out of the group of all students with SIS $\leq 120(N=580)$ to achieve parity in the gender distribution between the gifted and non-gifted groups. Then we ran an ANCOVA with giftedness as the independent variable. The gifted adolescents had a higher parental educational level $[t(396)=-2.51, p=0.01, d=0.25]$ and were somewhat younger than the non-gifted adolescents $[t(396)=0.92, p=0.36, d=0.09]$. Since both variables showed (small) correlations with life satisfaction (parental educational level: $r=-0.07, p=0.16$; age: $r=-0.30, p<0.001$ ), we included them as covariates in the ANCOVA.

To investigate whether gifted girls would display lower life satisfaction scores as compared with gifted boys, non-gifted girls, and non-gifted boys, we ran another ANCOVA on the entire sample, including both giftedness and gender as independent variables. Again, the covariates were age and parental educational level.

\section{Missing Data}

With the exception of parental educational level, there were no missing data. Regarding parental educational level, the missing data rate was $1.75 \%$. Little's test indicated that the data were missing completely at random $\left[\chi^{2}(33)=29.94, p=0.62\right]$. Nevertheless, to preserve good preconditions for matching, we did not opt for listwise deletion but instead imputed the missing values by means of an expectation maximization algorithm.

\section{RESULTS}

\section{Propensity Score Matching}

By means of 1:1 nearest neighbor matching without replacement, 74 of the 75 gifted students could be matched. Before testing for group differences, we inspected the quality of the matching results. First, we checked for the balance property. The overall balance test was not statistically significant $\left[\chi^{2}(3)=0.06\right.$,

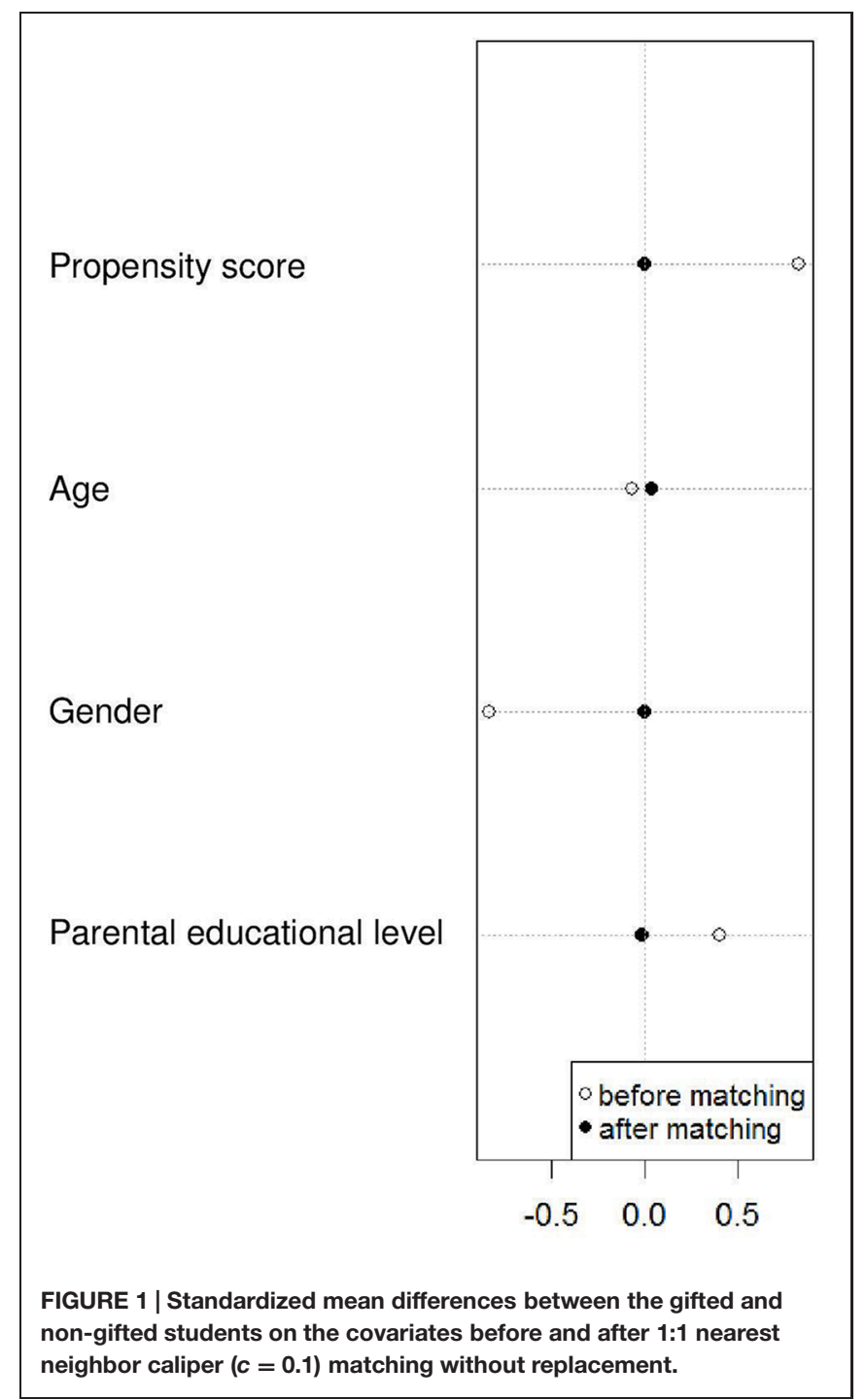

$p>0.99$ ], indicating excellent overall multivariate balance. As required, $L_{1}$ was smaller after matching $\left(L_{1}=0.27\right)$ than before matching $\left(L_{1}=0.48\right)$, suggesting good relative multivariate balance. Univariate analyses of differences in the means and variances of the covariates between the matched gifted and the matched non-gifted samples showed that matching was able to substantially reduce the differences in the means and also some differences in the variances of the covariates (see Figure $\mathbf{1}$ and Table 1).

As could already be inferred from the fact that a match was found for all but one gifted student, the area of common support was high. Figure 2 illustrates the distribution of propensity scores for all matched and unmatched gifted and non-gifted students. As can be seen, only one gifted student's propensity score was too high to be matched with a student from the non-gifted group. For all other gifted students, suitable counterparts were identified.

Thus, the matching procedure revealed both good balance on age, gender, and parental educational level and a high overlap between the gifted and the non-gifted group so that (1) the two 
TABLE 1 | Means (M), standard deviations (SD), and variance ratios (VR) of gifted and non-gifted students on the covariates before and after 1:1 nearest neighbor caliper $(c=0.1)$ matching without replacement.

\begin{tabular}{|c|c|c|c|c|c|c|c|c|}
\hline & \multicolumn{2}{|c|}{ Gifted } & \multicolumn{2}{|c|}{ Non-gifted } & \multirow[b]{2}{*}{ VR } & \multirow[b]{2}{*}{$t$} & \multirow[b]{2}{*}{$p$} & \multirow[b]{2}{*}{$d$} \\
\hline & $M$ & $S D$ & $M$ & $S D$ & & & & \\
\hline \multicolumn{9}{|l|}{ Before matching } \\
\hline Age & 16.61 & 0.72 & 16.66 & 0.70 & 1.05 & -0.57 & 0.57 & -0.06 \\
\hline Gender $(0=$ male, $1=$ female $)$ & 0.25 & 0.44 & 0.62 & 0.49 & 0.81 & -6.65 & $<0.01$ & -0.54 \\
\hline Parental educational level & 5.95 & 1.93 & 5.17 & 1.88 & 1.05 & 3.30 & $<0.01$ & 0.29 \\
\hline Age & 16.64 & 0.69 & 16.61 & 0.72 & 0.92 & 0.23 & 0.82 & 0.04 \\
\hline Gender $(0=$ male, $1=$ female $)$ & 0.26 & 0.44 & 0.26 & 0.44 & 1.00 & 0.00 & $>0.99$ & 0.00 \\
\hline Parental educational level & 5.92 & 1.93 & 5.95 & 1.87 & 1.07 & -0.09 & 0.93 & -0.01 \\
\hline
\end{tabular}

Before matching: $N=75$ (gifted group), $N=460$ (non-gifted group). After matching: $N=74$ (both groups). $V R=S^{2}$ gifted $/ S^{2}$ non-gifted. Positive $t$-and $d$-values: differences in favor of the gifted students.

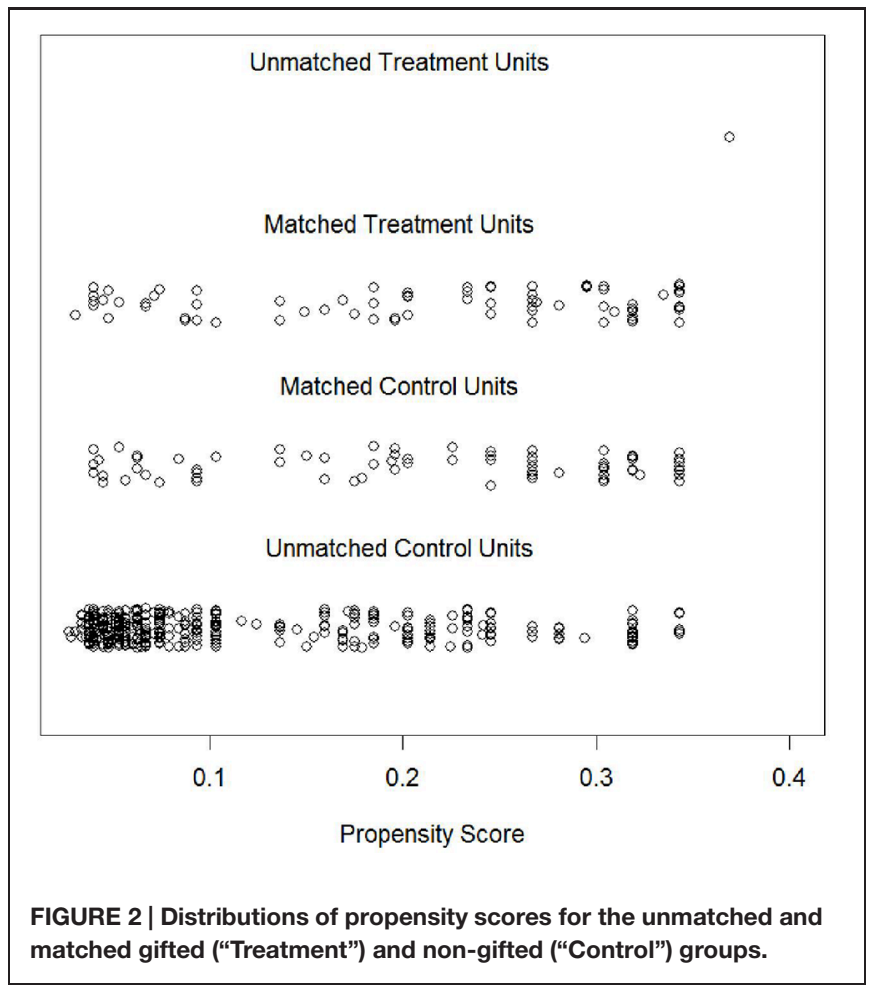

groups were comparable after matching and (2) the results were representative of a substantial array of our sample.

\section{Group Comparison}

After matching, we first computed a $t$-test for independent samples. Life satisfaction was nearly identical between the gifted $(M=4.65, S D=1.23)$ and non-gifted students $(M=4.69$, $S D=1.17)$. Accordingly, the difference that was found was neither statistically nor practically significant $[t(146)=-0.20$, $p=0.84, d=-0.03]$. We additionally conducted a $t$-test for dependent samples to account for the matched nature of our data. The results did not differ from the previous analysis $[t(73)=-0.30, p=0.77]$.
Despite a large area of common support, matched samples are always selected on certain characteristics. Therefore, we also tested whether the finding with a rather selected comparison group would hold when using a relatively unselected comparison group, drawing on a random sample with an adjusted gender distribution (see above). Again, the life satisfaction scores of gifted students $(M=4.65, S D=1.22)$ and non-gifted students $(M=4.64, S D=1.15)$ were virtually the same, and the difference was not statistically or practically significant $[F(1,394)=0.08$, $p=0.78, d=0.03]$. Of the covariates, the effect of age $\left[F(1,394)=38.56, p<0.001, \eta^{2}=0.089\right]$ was statistically and practically significant, with younger students reporting higher life satisfaction. We additionally ran an ANCOVA using the entire sample and controlling for gender. The results were virtually the same [with a significant effect of gender: $F(1,650)=17.27$, $\left.p<0.001, \eta^{2}=0.026\right]$.

We then included both giftedness and gender as independent variables in another ANCOVA to investigate both the main effect of gender on life satisfaction and the gender $\times$ giftedness interaction, using all available student data. Gifted boys displayed the highest life satisfaction scores $(M=4.84, S D=1.10)$, followed by non-gifted boys $(M=4.73, S D=1.12)$, non-gifted girls $(M=4.43, S D=1.22)$, and gifted girls $(M=4.11, S D=1.41)$. The main effect of gender (girls reporting lower life satisfaction than boys) was statistically significant $[F(1,649)=9.26, p=0.002$, $d=0.24]$. However, the gender $\times$ giftedness interaction was not, and the effect size was negligible $[F(1,649)=0.62, p=0.43$, $\left.\eta^{2}=0.001\right]$. The main effect of giftedness was again not statistically significant and negligible in size $[F(1,649)=0.46$, $p=0.50, d=-0.05]$.

\section{DISCUSSION}

So far, there have been only a few studies that have investigated whether intellectually gifted individuals report higher subjective well-being or life satisfaction, respectively, than non-gifted individuals. Even fewer studies have investigated life satisfaction, especially in gifted and non-gifted adolescents, and some of them have been limited by imprecise definitions of giftedness, 
high selectivity of samples, and a lack of appropriately matched non-gifted comparison groups (see Rost, 2009; Wirthwein and Rost, 2011). Moreover, other studies have frequently used teacher ratings to identify intellectually gifted individuals. In our study, we tried to avoid these methodological shortcomings. Giftedness was clearly defined as a SIS greater than $120(\mathrm{PR} \geq 98)$ in general reasoning ability as measured by the IST $2000 \mathrm{R}$. Regarding life satisfaction, we used a well-established German questionnaire (Dalbert, 2003). As we collected data from regular schools (as opposed to, e.g., special schools or classes for gifted students) and the participation rate was high, our samples could be assumed to display relatively low selectivity with regard to students attending the German Gymnasium. Furthermore, we ensured comparability between the gifted and non-gifted students by means of PSM and tested for the generalizability of our findings.

Our results indicated that there was no difference in life satisfaction between gifted and non-gifted students. This result emerged irrespective of whether we used a selected sample (PSM) versus a random sample or the entire sample (ANCOVA). It was also irrespective of the group comparison method within the PSM-matched samples (correcting vs. not correcting for the matched nature of the data). Although there was a slight variation in both the size and direction of Cohen's $d$ across our analyses, $d$ was clearly and consistently below $|0.1|$, suggesting that life satisfaction does not differ between intellectually gifted and intellectually non-gifted adolescents. This finding was not limited to a comparison with a preselected group of non-gifted students but was rather representative of the entire sample in our study. Our results are in contrast to studies that have suggested that gifted individuals display lower subjective well-being and more socio-emotional problems than non-gifted individuals do (see Neihart, 1999)often referred to as the disharmony hypothesis (e.g., Mönks, 1963). However, many such studies used highly selective gifted samples. Whenever differences between gifted and non-gifted individuals were found in social, emotional, or other personality variables, there were always sound studies that found no differences between the investigated groups (see Plucker and Callahan, 2008). Hence, it is extremely important to examine unselected samples and make comparisons with appropriate control groups. The results of our study are all the more convincing as our sample was not preselected, and students did not know whether they belonged to the gifted or non-gifted group.

Our findings are in line with other studies that drew on vastly unselected samples and also did not find any differences in subjective well-being or life satisfaction, respectively, between gifted and non-gifted students, even when controlling for confounds such as social and economic background (Ash and Huebner, 1998; Zeidner and Shani-Zinovich, 2011; for adults, see Wirthwein and Rost, 2011). Contrary to the assumptions made by Diener (1984) or Diener and Fujita (1995), intelligence might be a less relevant determinant of life satisfaction. In this context, Wilson (1967) already supposed that intelligence might not be very relevant to life satisfaction. Instead, he emphasized the relevance of personality, coping styles, and other life goals. In sum, as Eid and Larsen (2008, p. 5) stated, "no single condition or characteristic is sufficient to bring about happiness in itself."

We found that girls reported lower life satisfaction than boys $(d=0.24)$. However, this finding was not specific to giftedness but was instead found across the entire sample. This is closely tied to Wirthwein and Rost's (2011) finding that there was no significant interaction between giftedness and gender in their exploration of the life satisfaction of adults. Therefore, it can be concluded that intellectually gifted girls are not at higher risk for developing higher emotional or social problems compared with intellectually gifted boys or non-gifted girls (see Reis, 2004). According to most studies on gender differences in life satisfaction, there are only minimal gender differences (see Huebner and Diener, 2008). However, the fact that there was (at least) a small gender difference in life satisfaction in our study justified our matching for gender. The finding that boys reported somewhat higher life satisfaction than girls may be related to gender differences in other variables that might contribute to life satisfaction. Girls have been reported to show lower ability self-perceptions and self-efficacy than boys, to attribute success to external factors, and to attribute failure to low ability (e.g., Nicholls, 1979; Stetsenko et al., 2000; Steinmayr and Spinath, 2009). Furthermore, girls are known to experience more anxiety and have more trouble regulating negative emotions than boys (e.g., Bender et al., 2012). Against this background, slight differences in life satisfaction in favor of boys seem easy to understand.

One might argue that the sample under study was not representative as we recruited students from only the highest track in the German school system. As research indicates that educational level is associated with well-being (Easterbrook et al., 2015), the results we found might apply only to gifted students attending a Gymnasium. However, nearly all gifted students attend a Gymnasium in Germany. In the Marburg Giftedness Project (Rost, 1993, 2009; Wirthwein and Rost, 2011), 151 students out of $N=7023$ primary school students (third graders) were identified as being gifted, of which $n=136$ students later on attended a Gymnasium (Sparfeldt et al., 2006). Thus, about $90 \%$ of all German gifted students attend a Gymnasium. On the basis of this fact, it makes sense that the likelihood of identifying gifted students at a Gymnasium is very high. This is reflected by the fact that the percentage of gifted students in our sample was markedly higher than one might expect in a representative sample ( $11.5 \%$ compared with $2 \%)$. Thus, the Gymnasium is the type of school typically attended by gifted students in Germany. Therefore, the fact that we investigated only students attending a Gymnasium might not have influenced the results as much as may have been the case in other studies of life satisfaction that focused on independent variables other than giftedness.

However, not only the gifted but also the non-gifted students attending a Gymnasiums are a selected group and therefore more intelligent in comparison with students who do not attend a Gymnasium. Therefore, one might suppose that if we had used a non-Gymnasium comparison group, the gifted might have reported lower life satisfaction than the control group because being gifted would have been more salient and might therefore have provided a risk factor for being less socially accepted or integrated. However, studies have shown that gifted students are 
most often well integrated even in vastly unselected samples (e.g., elementary school children; Rost and Czeschlik, 1994a,b; Czeschlik and Rost, 1995). Furthermore, studies investigating the big-fish-little-pond-effect have provided support for the hypothesis that a comparison with classmates with a low ability level is even beneficial for the academic self-evaluation of gifted individuals (e.g., Zeidner and Schleyer, 1999; Preckel and Brüll, 2010; Arens and Watermann, 2015). And satisfaction with school is, in turn, significantly linked to general life satisfaction, especially among gifted students (Ash and Huebner, 1998).

Another potentially problematic aspect of our sample may be the underrepresentation of underachievers. As students attending a Gymnasium are highly selected on the basis of their scholastic achievement at the end of elementary school, gifted underachievers do not attend a Gymnasium as often as gifted achievers. For instance, only $61 \%$ of gifted underachievers (11 out of 18) in the Marburg Giftedness Project attended a Gymnasium. By contrast, the quota for the gifted achievers (who were carefully matched according to intelligence, gender, age, social background, and school environment) was 94\% (16 out of 17) (Sparfeldt et al., 2006). Therefore, it is possible that gifted underachievers were underrepresented in our gifted sample. As gifted underachievers have a more negative motivational profile and lower self-esteem than gifted and non-gifted achievers (Hanses and Rost, 1998), it may well be the case that gifted underachievers also have lower life satisfaction. However, the percentage of gifted underachievers in representative samples is always quite low. In the Marburg Giftedness Project, only 18 students out of a total of 7023 (i.e., $12 \%$ of all gifted students) were identified as gifted underachievers (Rost and Hanses, 1997; Sparfeldt et al., 2006). Thus, the likelihood that our results are markedly distorted by an underrepresentation of gifted underachievers is quite low.

\section{REFERENCES}

Amelang, M., and Steinmayr, R. (2006). Is there a validity increment for tests of emotional intelligence in explaining the variance of performance criteria? Intelligence 34, 459-468. doi: 10.1016/j.intell.2006.03.003

Arens, A. K., and Watermann, R. (2015). How an early transition to high-ability secondary schools affects students' academic self-concept: contrast effects, assimilation effects, and differential stability. Learn. Individ. Diff. 37, 64-71. doi: 10.1016/j.lindif.2014.11.007

Ash, C., and Huebner, E. S. (1998). Life satisfaction reports of gifted middle-school children. Sch. Psychol. Q. 13, 310-321. doi: 10.1037/h00 88987

Baudson, T. G., and Preckel, F. (2013). Teachers' implicit personality theories about the gifted: an experimental approach. Sch. Psychol. Q. 28, 37-46. doi: $10.1037 /$ spq0000011

Bender, P. K., Reinholdt-Dunne, M. L., Esbjørn, B. H., and Pons, F. (2012). Emotion dysregulation and anxiety in children and adolescents: gender differences. Pers. Individ. Diff. 53, 284-288. doi: 10.1016/j.paid.2012.03.027

Brand, C. (1996). The G Factor: General Intelligence and its Implications. Chichester: Wiley.

Bühner, M., Ziegler, M., Krumm, S., and Schmidt-Atzert, L. (2006). Ist der I-S-T 2000 R rasch-skalierbar? [Is the I-S-T 2000 R rasch scaleable?]. Diagnostica 52, 119-130. doi: 10.1026/0012-1924.52.3.119

Chapman, J. W., and McAlpine, D. D. (1988). Students' perceptions of ability. Gift. Child Q. 32, 222-225. doi: 10.1177/001698628803200107
Nevertheless, as our sample of gifted students was also rather small, future studies should try to replicate our results with larger samples that additionally comprise students from other school types, including gifted underachievers, to further enhance generalizability.

We used PSM to establish the comparability of the gifted and non-gifted groups. We used age, gender, and parental educational level as covariates to control for these potential nuisance variables. However, it would have been even better to include even more covariates, such as school environment (see Wirthwein and Rost, 2011). However, an analysis of a random sample drawn from all of the students we had at hand confirmed the results of the PSM.

We used only life satisfaction ratings. In future studies, it might be important to additionally focus on the affective components of subjective well-being (see Diener et al., 1999). Although there were no differences in positive or negative affect between gifted and non-gifted adults (Wirthwein and Rost, 2011), these components have yet to be investigated in gifted and nongifted adolescents.

Despite some limitations of our study, we were able to show that there was on average no difference in life satisfaction in a vastly unselected gifted sample of adolescents as compared with non-gifted adolescents. Therefore, the disharmony hypothesis was not supported by our data. We were also able to disconfirm the hypothesis that gifted girls are especially prone to socio-emotional problems. Our findings go closely together with the main findings from the 29-year longitudinal Marburg Giftedness Study (Rost, 1993, 2009; Wirthwein and Rost, 2011) and other methodologically sound studies (see Plucker and Callahan, 2008): giftedness is not at all a risk factor for impaired psycho-social well-being or psycho-social development.
Chmiel, M., Brunner, M., Keller, U., Schalke, D., Wrulich, M., and Martin, R. (2012). Does childhood general cognitive ability at age 12 predict subjective well-being at age 52? J. Res. Pers. 46, 627-631. doi: 10.1016/j.jrp.2012.0 6.006

Cohen, J. (1988). Statistical Power Analysis for the Behavioral Sciences, 2nd Edn. Hillsdale, NJ: Erlbaum.

Czeschlik, T., and Rost, D. H. (1988). Hochbegabte und ihre peers [Gifted and their peers]. Z. Pädagog. Psychol. 2, 1-23.

Czeschlik, T., and Rost, D. H. (1995). Sociometric types and children's intelligence. Br. J. Dev. Psychol. 13, 177-189. doi: 10.1111/j.2044-835X.1995.tb 00672.x

Dalbert, C. (2003). "Habituelle subjektive wohlbefindensskala (HSWBS) [Scale of habitual subjective well-being]," in Diagnostische Verfahren zu Lebensqualität und Wohlbefinden, eds J. Schumacher, A. Klaiberg, and E. Brähler (Göttingen: Hogrefe), 319-323.

Diener, E. (1984). Subjective well-being. Psychol. Bull. 95, 542-575. doi: 10.1037/0033-2909.95.3.542

Diener, E., and Fujita, F. (1995). Resources, personal strivings, and subjective wellbeing: a nomothetic and idiographic approach. J. Pers. Soc. Psychol. 68, 926-935. doi: 10.1037/0022-3514.68.5.926

Diener, E., Suh, E. M., Lucas, R. R., and Smith, H. L. (1999). Subjective well-being: three decades of progress. Psychol. Bull. 125, 276-302. doi: 10.1037/00332909.125.2.276

Easterbrook, M. J., Kuppens, T., and Manstead, A. S. R. (2015). The education effect: higher educational qualifications are robustly associated with 
beneficial personal and socio-political outcomes. Soc. Indic. Res. 1-38. doi: 10.1007/s11205-015-0946-1

Eid, M., and Larsen, R. J. (eds). (2008). The Science of Subjective Well-being. New York, NY: Guilford Press.

Gilman, R., and Huebner, S. (2003). A review of life satisfaction research with children and adolescents. Sch. Psychol. Q. 18, 192-205. doi: 10.1521/scpq.18.2.192.21858

Hansen, B. B., and Bowers, J. (2008). Covariate balance in simple, stratified and clustered comparative studies. Statist. Sci. 23, 219-236. doi: 10.1214/08-STS254

Hanses, P., and Rost, D. H. (1998). Das “Drama” der hochbegabten underachiever "Gewöhnliche" oder "außergewöhnliche" Underachiever? [The "drama" of the gifted underachievers - "ordinary" or "extraordinary" underachievers?]. Z. Pädagog. Psychol. 12, 53-71.

Huebner, E. S., and Alderman, G. L. (1993). Convergent and discriminant validation of a children's life satisfaction scale: its relationship to self- and teacher-reported psychological problems and school functioning. Soc. Indic. Res. 30, 71-82. doi: 10.1007/BF01080333

Huebner, E. S., and Diener, C. (2008). "Research on life satisfaction of children and youth," in The Science of Subjective Well-Being, eds M. Eid and R. J. Larsen (New York, NY: Guilford Press), 376-392.

Iacus, S. M., King, G., and Porro, G. (2012). Causal inference without balance checking: coarsened exact matching. Polit. Anal. 20, 1-24. doi: 10.1093/pan/mpr013

Jensen, A. R. (1998). The G Factor: The Science of Mental Ability. Westport, CT: Praeger.

Jin, S.-U., and Moon, S. M. (2006). A study of well-being and school satisfaction among academically talented students attending a science high school in Korea. Gift. Child Q. 50, 169-184. doi: 10.1177/001698620605000207

Jones, T. W. (2014). Equally cursed and blessed: do gifted and talented children experience poorer mental health and psychological well-being? Educ. Child Psychol. 30, 44-66.

Kirkcaldy, B., Furnham, A., and Siefen, G. (2004). The relationship between health efficacy, educational attainment, and well-being among 30 nations. Euro. Psychol. 9, 107-119. doi: 10.1027/1016-9040.9.2.107

Liepmann, D., Beauducel, A., Brocke, B., and Amthauer, R. (2007). IntelligenzStruktur-Test 2000 R, 2 Erweiterte und Überarbeitete Auflagw [IntelligenceStructure-Test 2000 R, 2nd Extended and Revised Edn]. Göttingen: Hogrefe.

Loeb, R. C., and Jay, G. (1987). Self-concept in gifted children: differential impact in boys and girls. Gift. Child Q. 31, 9-14. doi: 10.1177/001698628703100102

Lubinski, D., Benbow, C. P., and Kell, H. J. (2014). Life paths and accomplishments of mathematically precocious males and females four decades later. Psychol. Sci. 25, 2217-2232. doi: 10.1177/0956797614551371

Lubinski, D., Benbow, C. P., Webb, R. M., and Bleske-Rechek, A. (2006). Tracking exceptional human capital over two decades. Psychol. Sci. 17, 194-199. doi: 10.1111/j.1467-9280.2006.01685.x

Lucas, R. E. (2008). "Personality and subjective well-being," in The science of Subjective Well-Being, eds R. J. Larsen and M. Eid (New York, NY: Guilford Press), 171-194.

Martin, L. T., Burns, R. M., and Schonlau, M. (2010). Mental disorders among gifted and nongifted youth: a selected review of the epidemiologic literature. Gift. Child Q. 54, 31-41. doi: 10.1177/0016986209352684

Mönks, F. J. (1963). Beiträge zur begabtenforschung im kindes- und jugendalter [Contributions to giftedness research from childhood to youth]. Arch. Psychol. $115,362-382$.

Mönks, F. J. (1990). Hochbegabtenförderung als aufgabe der pädagogischen psychologie [Gifted education as a task of Educational Psychology]. Psychol. Erzieh. Unterr. 37, 243-250.

Neihart, M. (1999). The impact of giftedness on psychological well-being: what does the empirical literature say? Roeper Rev. 22, 10-17. doi: 10.1080/02783199909553991

Neitzke, C., and Röhr-Sendlmeier, U. M. (1992). Achievement motivation of intellectually gifted pupils when confronted with challenging and unchallenging tasks. Euro. J. High Ability 3, 197-205. doi: 10.1080/09374459200 30208

Nicholls, J. G. (1979). Development of perception of own attainment and causal attributions for success and failure in reading. J. Educ. Psychol. 71, 94-99. doi: 10.1037/0022-0663.71.1.94
Owuchi, G., and Yoshino, H. (1975). A study on the happiness of pupil in school. Tohoku Psychol. Folia 34, 27-32.

Pavot, W., Diener, E., Colvin, C. R., and Sandvik, E. (1991). Further validation of the Satisfaction with Life Scale: evidence for the cross-method convergence of wellbeing measures. J. Pers. Assess. 57, 149-161. doi: 10.1207/s15327752jpa5701_17

Plucker, J., and Callahan, C. M. (eds). (2008). Critical Issues(and )Practices in Gifted Education: What the Research Says. Waco, TX: Prufrock Press.

Preckel, F., and Brüll, M. (2010). The benefit of being a big fish in a big pond: contrast and assimilation effects on academic self-concept. Learn. Individual Diff. 20, 522-531. doi: 10.1016/j.lindif.2009.12.007

Reis, S. M. (2004). "We can't change what we don't recognize: understanding the special needs of gifted females," in Twice-Exceptional and Special Populations of Gifted Students, ed. S. Baum (Thousand Oaks, CA: Corwin Press), 67-80.

Renzulli, J. S. (1978). What makes giftedness? Reexamining a definition. Phi Delta Kappan 60, 180-184, 261.

Robinson, N. M. (2005). "In defense of a psychometric approach to the definition of academic giftedness. A conservative view from a die-hard liberal," in Conceptions of Giftedness, 2nd Edn, eds R. J. Sternberg and J. E. Davidson (New York, NY: Cambridge University Press), 280-294.

Rode, J. C., Mooney, C. H., Arthaud-Day, M. L., Near, J. P., Rubin, R. S., Baldwin, T. T., et al. (2008). An examination of the structural, discriminant, nomological, and incremental predictive validity of the MSCEIT V2.0. Intelligence 36, 350-366. doi: 10.1016/j.intell.2007.07.002

Rosenbaum, P. R., and Rubin, D. B. (1983). The central role of the propensity score in observational studies for causal effects. Biometrika 70, 41-55. doi: 10.1093/biomet/70.1.41

Rost, D. H. (1990). Identificatie van hoogbegaafdheid [Identification of giftedness]. Ned. Tijdschr. Voor Opvoed. Vorm. Onderwijs 6, 122-151.

Rost, D. H. (ed.). (1993). Lebensumweltanalyse Hochbegabter Kinder [LifeEnvironmental analysis of gifted children]. Göttingen: Hogrefe.

Rost, D. H. (ed.). (2009). Hochbegabte und Hochleistende Jugendliche. Befunde aus dem Marburger Hochbegabtenprojekt [Gifted and High Achieving Youths. Findings from the Marburg Giftedness Project], 2nd Edn. Münster, Germany: Waxmann.

Rost, D. H. (2013). Handbuch Intelligenz [Handbook of Intelligence]. Weinheim: Beltz.

Rost, D. H., and Czeschlik, T. (1994a). Beliebt und intelligent? Abgelehnt und dumm? - eine soziometrische studie an 6500 grundschulkindern [Popular and intelligent? Rejected and dumb? - a sociometric study with 6500 primary school children]. Z. Sozialpsychol. 25, 170-176.

Rost, D. H., and Czeschlik, T. (1994b). The psycho-social adjustment of gifted children in middle childhood. Euro. J. Psychol. Educ. 9, 15-25. doi: 10.1007/BF03172882

Rost, D. H., and Hanses, P. (1997). Wer nichts leistet, ist nicht begabt? Zur Identifikation hochbegabter underachiever durch lehrkräfte [Not achieving not gifted? About the identification of gifted underachievers by teacher-ratings]. Z. Entwicklungspsychol. Pädagog. Psychol. 29, 167-177.

Roznowski, M., Reith, J., and Hong, S. (2000). A further look at youth intellectual giftedness and its correlates: values, interests, performance, and behavior. Intelligence 28, 87-113. doi: 10.1016/S0160-2896(99)00032-X

Schilling, S. R. (2002). Hochbegabte Jugendliche und ihre Peers [Gifted Youths and Their Peers]. Münster: Waxmann.

Schmidt-Atzert, L., and Rauch, W. (2008). Intelligenz-Struktur-Test 2000 R (I-S-T 2000 R). 2., erweiterte und überarbeitete auflage [TBS-TK Rezension] [TBS-TK review. Intelligence-Structure-Test 2000 R (I-S-T 2000 R). 2nd Extended and Revised Edn]. Rep. Psychol. 33, 303-304.

Schütz, C. (2009). "Leistungsbezogene kognitionen [Achievement-related cognitions]," in Hochbegabte und Hochleistende Jugendliche. Befunde aus dem Marburger Hochbegabtenprojekt, ed. D. H. Rost (Münster: Waxmann), 303-337.

Sears, R. R. (1977). Sources of life satisfaction of the terman gifted men. Am. Psychol. 32, 119-128. doi: 10.1037/0003-066X.32.2.119

Shaunessy, E., Suldo, S. M., Hardesty, R. B., and Shaffer, E. J. (2006). School functioning and psychological well-being of international baccalaureate and general education students. A preliminary examination. J. Second. Gift. Educ. $17,76-89$.

Sparfeldt, J. R., Schilling, S. R., and Rost, D. H. (2006). Hochbegabte Underachiever als Jugendliche und Erwachsene. Des dramas zweiter akt? 
[Gifted underachievers as adolescents and young adults: second part of the "drama of gifted underachievers?"]. Z. Pädagog. Psychol. 20, 213-224.

Spearman, C. (1904). "General intelligence," objectively determined and measured. Am. J. Psychol. 15, 201-292. doi: 10.2307/1412107

Spearman, C. (1927). The Abilities of Men. New York, NY: Macmillan.

Steinmayr, R., Beauducel, A., and Spinath, B. (2010). Do sex differences in a faceted model of fluid and crystallized intelligence depend on the method applied? Intelligence 38, 101-110. doi: 10.1016/j.intell.2009.08.001

Steinmayr, R., and Spinath, B. (2009). What explains boys' stronger confidence in their intelligence? Sex Roles 61, 736-749. doi: 10.1007/s11199-009-9675-8

Sternberg, R. J., and Davidson, J. E. (2005). Conceptions of Giftedness, 2nd Edn. New York, NY: Cambridge University Press. doi: 10.1017/CBO9780511610455

Stetsenko, A., Little, T. D., Gordeeva, T., Grasshof, M., and Oettingen, G. (2000). Gender effects in children's beliefs about school performance: a cross-cultural study. Child Dev. 71, 517-527. doi: 10.1111/1467-8624.00161

Stuart, E. A. (2010). Matching methods for causal inference: a review and a look forward. Statist. Sci. 25, 1-21. doi: 10.1214/09-STS313

Suldo, S. M., Riley, K. N., and Shaffer, E. J. (2006). Academic correlates of children and adolescents' life satisfaction. Sch. Psychol. Int. 27, 567-582. doi: $10.1177 / 0143034306073411$

Swiatek, M. A., and Benbow, C. P. (1991). Ten-year longitudinal follow-up of ability-matched accelerated and unaccelerated gifted students. J. Educ. Psychol. 83, 528-538. doi: 10.1037/0022-0663.83.4.528

Terman, L. M., Baldwin, B. T., and Bronson, E. (1925). "Mental and physical traits of a thousand gifted children," in Genetic Studies of Genius, Vol. 1, ed. L. M. Terman (Stanford, CA: Stanford University Press).

Thoemmes, F. J., and Kim, E. S. (2011). A systematic review of propensity score methods in the social sciences. Multivar. Behav. Res. 46, 90-118. doi: 10.1080/00273171.2011.540475
Thompson, L. A., and Oehlert, J. L. (2010). The etiology of giftedness. Learn. Individual Diff. 20, 298-307. doi: 10.1016/j.lindif.2009.11.004

Watten, R. G., Syversen, J. L., and Myhrer, T. (1995). Quality of life, intelligence and mood. Soc. Indic. Res. 36, 287-299. doi: 10.1007/BF01078818

Wilson, W. (1967). Correlates of avowed happiness. Psychol. Bull. 67, 294-306. doi: $10.1037 / \mathrm{h} 0024431$

Wirthwein, L., and Rost, D. H. (2011). Giftedness and subjective wellbeing: a study with adults. Learn. Individual Diff. 21, 182-186. doi: 10.1016/j.lindif.2011.01.001

Zeidner, M., and Schleyer, E. J. (1999). The big-fish-little-pond effect for academic self-concept, test anxiety, and school grades in gifted children. Contemp. Educ. Psychol. 24, 305-329. doi: 10.1006/ceps.199 8.0985

Zeidner, M., and Shani-Zinovich, I. (2011). Do academically gifted and nongifted students differ on the Big-Five and adaptive status? Some recent data and conclusions. Pers. Individ. Diff. 51, 566-570. doi: 10.1016/j.paid.2011.05.007

Ziegler, A., and Raul, T. (2000). Myth and reality: a review of empirical studies on giftedness. High Ability Stud. 11, 113-136. doi: 10.1080/13598130020001188

Conflict of Interest Statement: The authors declare that the research was conducted in the absence of any commercial or financial relationships that could be construed as a potential conflict of interest.

Copyright () 2015 Bergold, Wirthwein, Rost and Steinmayr. This is an open-access article distributed under the terms of the Creative Commons Attribution License (CC BY). The use, distribution or reproduction in other forums is permitted, provided the original author(s) or licensor are credited and that the original publication in this journal is cited, in accordance with accepted academic practice. No use, distribution or reproduction is permitted which does not comply with these terms. 